\title{
Small mammal assemblages and their ectoparasite prevalence (Acarina) in mangrove forests of Peninsular Malaysia
}

\author{
Farah Shafawati Mohd-Taib*, Rosha Asyikha and Shukor Md. Nor \\ Department of Biological Sciences and Biotechnology, Faculty of Science and Technology, Universiti \\ Kebangsaan Malaysia, Bangi, Selangor, Malaysia
}

Received for publication: 20 November 2020; Revision received: 21 July 2021; Accepted for publication: 30 July 2021.

\begin{abstract}
The mangrove forest is located in the coastal intertidal zone and plays a vital role in buffering against erosion from storm surges, currents, waves, and tides. This ecosystem also serves for ecotourism due to its heterogeneous habitats, which supported a high diversity of plants and animals. Small mammals are among the abundant but poorly recognised inhabitants in mangrove forests. Apart from their role as primary consumer and prey, they are host to various ectoparasites, which potentially become the primary vector for tick-borne diseases among visitors. Therefore, this study aims to determine the small mammal assemblages and their ectoparasite prevalence in mangroves forests of Peninsular Malaysia. The capture-release method was applied for small mammal sampling, and each captured individual was screened and collected for ectoparasites before released. DNA barcoding using $\mathrm{CO} 1$ genes was performed for small mammal species verification, whereby ectoparasite identification was based on morphological identification and molecular verification using $16 \mathrm{~S}$ rDNA genes. A total of 94 small mammals from 6 species were captured across sites, dominated by Rattus tiomanicus $(\mathrm{n}=74)$. From this number, 15 individuals $(16 \%$ prevalence) were infested by ticks, 22 individuals (23\%) were infested by mites, whereas 4 individuals (4\%) were infested by both ticks and mites. Five species of ticks and one mite species were identified; Amblyomma cordiferum, Ixodes granulatus, Haemaphysalis hystricis, Dermacentor auratus, Dermacentor atrosignatus, and Laelaps echidninus. This study reveals a relatively poor diversity of small mammals in the mangroves forest, of which highly infested with a diversity of ectoparasites, elucidating the relationship of hostectoparasite associations in the riparian zone. This information is crucial to inform visitors to these areas, ultimately safeguard against ectoparasite-borne disease.
\end{abstract}

Key words: Ectoparasite; rodent; riparian zone; PCR detection; prevalence; Malaysia.

\section{Introduction}

The mangrove forest is a wetland ecosystem that plays a crucial role in stabilising and protecting the shorelines from increased storm surge, flooding, and hurricanes. It is also

\footnotetext{
*Corresponding author. E-mail: farah_sh@ukm.edu.my

${ }^{\circ}$ Copyright: the Author(s), $2021 \mid$ Licensee PAGEPress, Italy
} 
considered one of the most productive ecosystems, which hosts a diversity of flora and fauna (Sundararaman et al. 2007; Jusoff 2013). This ecosystem provides economic and social benefits (Ashton and Macintosh 2002) to human livelihood. However, the unique coastal mangrove resources have been exploited for many purposes, such as timber harvesting for the charcoal industry, aquaculture, agriculture, fisheries, residential, industrial, and urbanisation (Chong 2006). These anthropogenic disturbances, along with natural events, have consequently threatened mangrove ecosystems worldwide (Schipper et al. 2008; Polidoro et al. 2010).

Mangroves serve as habitat, nurseries, and breeding grounds for various marine animals, including crustaceans and fishes (Barbier and Strand 1998), as well as terrestrial animals. Many animals are highly dependent on mangroves, particularly concerning food resources, shelter, and their interaction with non-living components in the mangrove ecosystems (Kathiresan 2000). For instance, large predators such as snakes, owls, and eagles hunt a wide variety of preys like rats and small birds. Small mammals like rodents thrive in this ecosystem due to their high adaptability to a variety of living conditions (Tripathi 2014). This group of animals also plays a vital role in mangrove ecosystems as pollinating agents (squirrels and bats), pest control among insects and molluscs, as well as biological indicators of forest ecosystem health (Khan 2012). Nonetheless, the literature on the assemblage of terrestrial vertebrates, especially on small mammals in mangrove forests, is scarce (Luther and Greenberg 2009; Hogarth 2015). Thus, it is imperative to understand the species assemblages present. Besides, anthropogenic disturbances, including deforestation, habitat destruction, and unsustainable harvesting of the forest products pose significant threats to mangrove-dependent species (Kairo et al. 2001), including small mammals and other wildlife species (Kathiresan and Bingham 2001).

Ectoparasites, including mites, lice, fleas, and ticks are often associated with small mammals as their main hosts (Eslami et al. 2018). Several studies have revealed that small mammals like rodents and tree shrews are important hosts for ectoparasites (Paramasvaran et al. 2009; Madinah et al. 2011; Mohd Zain et al. 2015; Ernieenor et al. 2016; Ishak et al. 2018b; Razali et al. 2018). Ishak et al. (2018b) reported relatively low diversity of ticks in small mammals in a tropical lowland dipterocarp forest. Meanwhile, Eslami et al. (2018) revealed that a rodent species, Rattus rattus (Linnaeus, 1758), was highly infested by three ectoparasite species from the mangrove forest in Qeshm Island, Iran. Nevertheless, there are still no detailed studies on the prevalence of ectoparasites on small mammals in mangrove forests, specifically in Southeast Asia. The presence of ectoparasites in an area is influenced by the composition and abundance of the small mammal inhabitants (Dobson et al. 2016). Therefore, ectoparasite movement is highly dependent on the community and distribution of their hosts (Estrada-Peña and de la Fuente 2014). Ticks (Acari: Ixodida) are obligate blood-feeding parasites of terrestrial vertebrates, grouped into three families, i.e., Ixodidae (hard ticks), Argasidae (soft ticks), and Nuttalliellidae (Horak et al. 2002). Hard ticks could be found in areas with abundant vegetation and more temperate climates, whereas soft ticks are more resilient and live in a more barren and arid zone (Kröber and Guerin 2007). Both groups are important vectors of various pathogens of veterinary and medical concern (Sarwar 2017). Mites are smaller Acari under the class Arachnida. They are divided into four types, namely mesostigmatid, chiggers (larvae), myobiids and listrophorids (Mohd-Zain et al. 2015). Laelaps echidninus Berlese, 1887 is one of the mite species in the family Laelapidae that is often associated with small mammals, where this species tends to infect rodent species like Rattus norvegicus (Berkenhout, 1769) (BaakBaak et al. 2016). 
Small mammals have also been reported as primary hosts of various pathogens vectored by these ectoparasites, which can also be transmitted to humans (Tripathi 2014). Many species of ectoparasites are of substantial interest and value as vectors of a wide variety of pathogens, such as the Lyme disease, meningoencephalitis, babesiosis, ehrlichiosis, and tularaemia to both humans and animals (Pulscher et al. 2018; Heukelbach et al. 2012). For instance, Rickettsia helvetica is spread primarily by tick species and is responsible for spotted fever (Dobec et al. 2009), whereas Anaplasma phagocytophilum (human granulocytic anaplasmosis agent) transmission occurs by Ixodid ticks, with rodents as host (de la Fuente et al. 2016). Orientia tsutsugamushi is responsible for scrub typhus, which is transmitted by mites (chiggers; Rodkvamtook et al. 2018). Apart from that, Haddad et al. (2018) described that the small bites from ticks could cause severe injury and direct damage, leading to toxic circumstances like paralysis, irritation, and allergies in animals and humans.

In the present study, we determined the ectoparasite diversity and prevalence from small mammals captured in three mangroves areas in Peninsular Malaysia. These mangrove sites have undergone varying anthropogenic pressures, which resulted in a reduced mangrove cover, and increased anthropogenic activities (horticulture, urbanisation, and monoculture plantation activities). Apart from tourism, these habitats continue to provide resources for the local community's livelihood, including seafood products and logs for charcoal production. This study is pioneer in documenting the ectoparasite assemblages infesting small mammals in mangrove ecosystem; thus, the potential infestation to the local communities, as well as visitors to these areas.

\section{Material and methods}

\section{Study sites}

The study was conducted at three mangrove forests of Peninsular Malaysia, in the state of Terengganu (KSY), Negeri Sembilan (KST), and Perak (KDP) (Figure 1). Sampling was carried out in two phases at each location, between December 2017 and August 2018, with seven days of continuous trapping per phase, at each location. Sampling was conducted at five stations along a $1 \mathrm{~km}$ stretch from the jetty, following the river at each mangrove site. Each station was not further than $300 \mathrm{~m}$ from the riverbank.

\section{Small mammals trapping and species identification}

A total of 125 wired mesh cage traps $(28 \mathrm{~cm} \times 15 \mathrm{~cm} \times 12.5 \mathrm{~cm})$ were deployed randomly at five research stations in each mangrove forest ( 25 cages/station). These cages were baited with different types of aromatic baits, including banana, oil palm fruit, and jackfruit (Bernard et al. 2004) in equal amounts, and were placed on tree stumps, fallen logs, and at ground level (Balete et al. 2009; Rickart et al. 2011). All traps were checked twice a day at 0900 hours and 1700 hours. Captured individuals were marked with an ear tag with an ID number. However, in this study, recaptured animals were not considered as a new individual. All captured individuals were anaesthetised (Massolo et al. 2003), with a volume between $0.1-0.3 \mathrm{ml}$ of Zoletil $100 \AA$ injected intramuscularly according to the weight of the animal. As soon as the animals lost consciousness, the standard external measurements were recorded, including the length of tail, whole body, head, ears, and foot patch using a Vernier calliper and measuring tape. Species identifications were based on the morphological measurements, as well as physical features such as fur and tail colour, following Francis (2008). In addition, the tip of the tail (tissue samples) was cut off from 
each individual, for species verification using barcoding, targeting on the CO1 genes, according to Li et al. (2014). Small mammal trapping and handling procedures were approved by the animal research ethics committee of Universiti Kebangsaan Malaysia (FST/2020/FARAH SHAFAWATI/16-JAN./1080-FEB.-2020-FEB.-2022-NAR-CAT2).

\section{Ectoparasite collection and morphological identification}

Ectoparasites were identified based on morphological observations using a stereomicroscope and further verified with molecular methods. Each host was carefully combed for ectoparasites (ticks and mites) and collected using tweezers and placed individually in labelled cryo-vials containing 70\% alcohol for preservation. For morphological identification, the ectoparasites were observed under a stereomicroscope (Motic SMZ-168 Stereo Zoom microscope; Motic, Hong Kong) to inspect the basic features, and identify the samples up to genus level, as well as to classify the developmental stage (larvae, nymph, or adult) and sex followed Strandtmann and Mitchell 1963; Yamaguti et al. 1971; Baker 1999; Walker et al. 2007). Next, ectoparasite species identifications were confirmed by a molecular approach based on 16S rRNA gene (Black and Piesman 1994). Prior to this, each ectoparasite individual was surface sterilised by rinsing with $70 \%$ ethanol solution, followed by washing in sterile distilled water to eliminate debris from possible environmental pollution (Carpi et al. 2011).

\section{DNA extraction and PCR analysis}

DNA from ticks and mites was extracted using the HiYield Plus Genomic DNA Mini Kit (Real Biotech Corporation [RBC], Taiwan), according to the manufacturer's protocol.

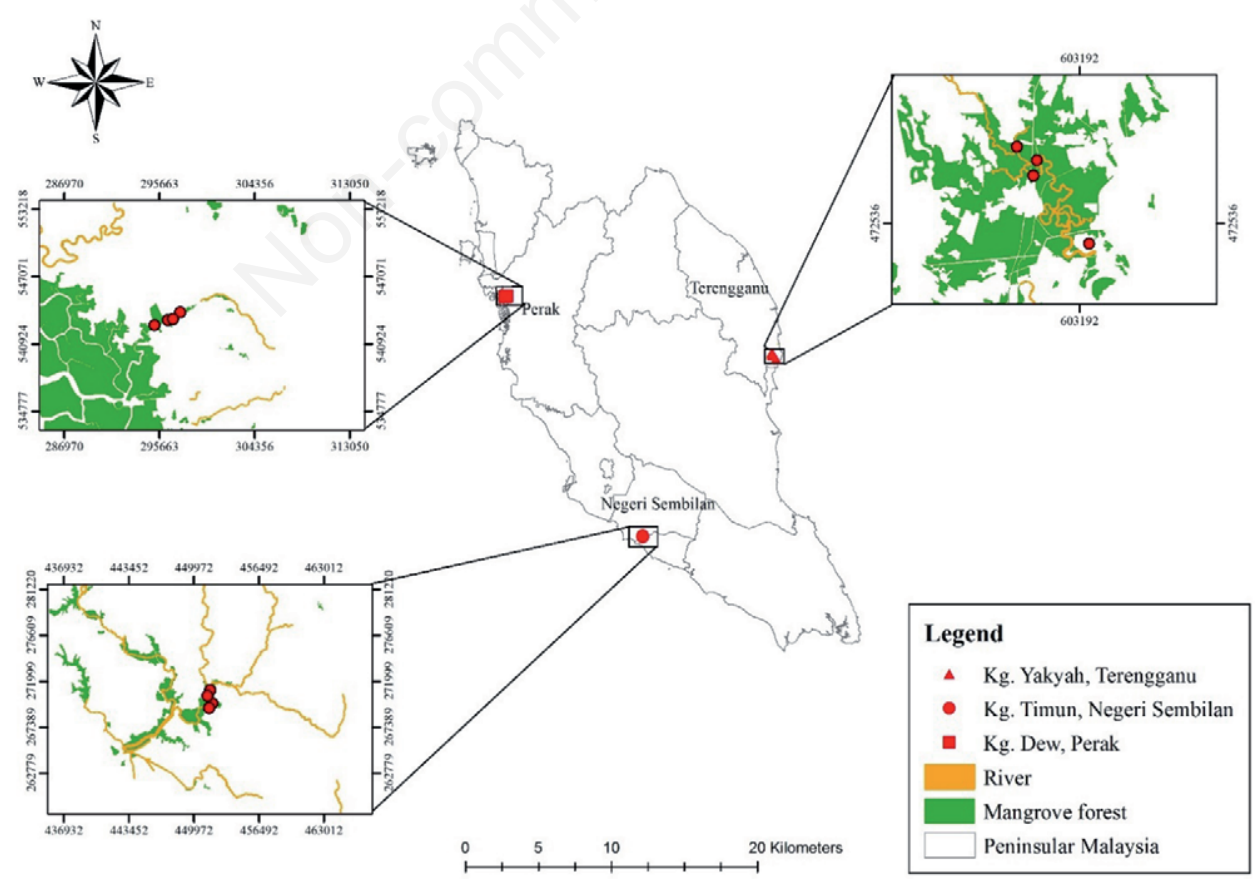

Figure 1. Location of mangrove sites at Kg. Dew, Perak (KDP), Kg. Yakyah, Terengganu (KSY) and Kg. Timun, Negeri Sembilan (KST) in Peninsular Malaysia. 
DNA was extracted by adding $500 \mu \mathrm{L}$ of phosphate-buffered saline (PBS) to the sample. Then, $200 \mu \mathrm{L}$ of QGT Buffer and $20 \mu \mathrm{L}$ of Proteinase K were added. The samples were vortexed and incubated at $60^{\circ} \mathrm{C}$ overnight until the sample lysate became clear. PCR amplification was initially performed to amplify mitochondrial rDNA gene for the ectoparasites, with the primer set designed by Black and Piesman (1994), namely, 16S +1 for the forward strand (5'-CTGCTCAATGATTTTTTAAATTGCTGTGG-3') and 16S-1 for the reverse strand (5' -CCGGTCTGAACTCAGATCAAGT-3'). The PCR was performed using an Alpha Cycler PCRmax machine (PCRmax, UK). The 16S rDNA gene amplification program was conducted as follows; initial denaturation at $95^{\circ} \mathrm{C}(5 \mathrm{~min})$, followed by 10 cycles of denaturation at $92^{\circ} \mathrm{C}(1 \mathrm{~min}), 48^{\circ} \mathrm{C}(1 \mathrm{~min})$, and $72^{\circ} \mathrm{C}(1.5 \mathrm{~min})$. Then, continued with 32 cycles of $92^{\circ} \mathrm{C}(1 \mathrm{~min}), 54^{\circ} \mathrm{C}(35 \mathrm{sec}), 72^{\circ} \mathrm{C}(1.5 \mathrm{~min})$, and followed by a final extension step at $72^{\circ} \mathrm{C}(7 \mathrm{~min})$. Nuclease free water was used as the negative control to replace the DNA template. Next, the amplified products were electrophoresed on $1.0 \%$ agarose gel and viewed under an ultraviolet (UV) transilluminator. DNA purification and sequencing analysis were performed by MyTACG Bioscience Enterprise (Malaysia).

\section{Sequencing alignment and phylogenetic analysis}

Representative DNA sequences of ectoparasite species, animal host species, and the sampling sites, were used in a BLAST search (http:/www.ncbi.nlm.nih.gov/BLAST) and aligned with other ectoparasite reference sequences available in the GenBank. The new accession numbers of all ectoparasite sequences created from the GenBank were mentioned. Analysis of multiple sequence alignment of $16 \mathrm{~S}$ rDNA sequences was generated with the Muscle software tool in the MEGA (Molecular Evolutionary Genetics Analysis) software version 7, as defined by Kumar et al. (2016). The results of DNA sequences were exported as FASTA format files. A phylogenetic tree was constructed by neighbour-joining (NJ) based on the Kimura two-parameter model (K2) to conclude the relationships within and between the ectoparasite species. NJ tree was performed using both sequences of tick and mite samples in this study and other reference sequences from the GenBank. Pairwise sequence comparison was performed using the MEGA software version 7 based on $16 \mathrm{~S}$ rRNA genes.

\section{Data analysis}

To distinguish the completeness of sampling effort, individual-based rarefaction curves were constructed (Entsminger 2012; Mohd-Taib et al. 2020) for each site using EcoSim 700 software version 7.71 (Acquired Intelligence Inc. 2018). Ectoparasite abundance was calculated for every small mammal individual captured. In epidemiological studies, prevalence is calculated based on all individuals affected by the disease at a time (Shields and Twycross 2003) and stretches a figure for a factor at a single point in time (Jekel et al. 2001). From this study, the prevalence of small mammal species infested with ticks and mites was calculated according to Akucewich et al. (2002), using the formula below:

$$
=\frac{\text { Number of infested small mammals }}{\text { Total number of small mammals captured }} \times 100 \%
$$

Next, an independent sample t-test was used to ascertain the differences between ectoparasite infestations on male and female hosts, using SPSS version 23 (IBM Corporation). 


\section{Results}

\section{Small mammal assemblages and their ectoparasite prevalence at mangrove areas}

A total of 94 small mammals belonging to six species [Rattus tiomanicus (Miller, 1900), Rattus rattus diardii (Linnaeus, 1758), Maxomys whiteheadi (Thomas, 1894), Sundamys muelleri (Jentink, 1879), Tupaia glis (Diard, 1820), and Callosciurus notatus (Boddaert, 1785)] and two orders (Rodentia and Scandentia) were trapped from the three different mangrove sites. The barcoding results of different species are illustrated in Table 1 , and the distribution of small mammal species are listed in Table 2. The most abundant small mammal species trapped from this study is $R$. tiomanicus (Malaysian wood rat; $78.7 \%, \mathrm{n}=74)$, followed by T. glis $(9.6 \%, \mathrm{n}=9)$, and S. muelleri $(5.3 \%, \mathrm{n}=5)$. The least abundant host species was $M$. whiteheadi $(1.06 \%, \mathrm{n}=1)$. Each mangroves site recorded three small mammal species, with KDP recording the highest abundance with 42 individuals, followed by KST (36 individuals), and the least at KSY, with 16 individuals. The Shannon diversity index was slightly higher at KSY (0.7029), followed by KDP (0.6948), and KST (0.5503). In addition, rarefaction curves demonstrated that nearly all study sites

Table 1. List of the different species of small mammals and BLAST results from the GenBank.

\begin{tabular}{|c|c|c|c|c|}
\hline \multirow[t]{2}{*}{ ID code } & \multirow{2}{*}{$\begin{array}{l}\text { Mangrove } \\
\text { area }\end{array}$} & \multicolumn{2}{|c|}{ Host species (Identification) } & \multirow{2}{*}{$\begin{array}{c}\text { Similarity } \\
\text { with } \\
\text { GenBank, \% }\end{array}$} \\
\hline & & Morphology & Molecular & \\
\hline PKY010 & KSY & Rattus sp. & Rattus tiomanicus & 98 \\
\hline PKY012 & & Rattus sp. & Rattus tiomanicus & 98 \\
\hline PKY002 & & Rattus rattus & Rattus rattus diardii & 99 \\
\hline PKY009 & & Rattus rattus & Rattus rattus diardii & 98 \\
\hline PKY004 & & Maxomys whiteheadi & Maxomys whiteheadi & 99 \\
\hline STM032 & KST & Rattus sp. & Rattus tiomanicus & 99 \\
\hline STM001 & & Tupaia glis & Tupaia glis & 99 \\
\hline STM014 & & Tupaia glis & Tupaia glis & 99 \\
\hline STM015 & & Callosciurus notatus & Callosciurus notatus & 99 \\
\hline STM020 & & Callosciurus notatus & Callosciurus notatus & 99 \\
\hline KDM016 & KDP & Rattus sp. & Rattus tiomanicus & 99 \\
\hline KDM006 & & Sundamys muelleri & Sundamys muelleri & 99 \\
\hline KDM036 & & Sundamys muelleri & Sundamys muelleri & 99 \\
\hline KDM004 & & Tupaia glis & Tupaia glis & 99 \\
\hline KDM012 & & Tupaia glis & Tupaia glis & 100 \\
\hline
\end{tabular}

Table 2. Species distribution of small mammals at different mangrove sites.

\begin{tabular}{lcccc} 
Small mammal species & KSY & KST & KDP & Total \\
Rattus tiomanicus & 12 & 27 & 35 & $\mathbf{7 4}$ \\
\hline Tupaia glis & 0 & 7 & 2 & $\mathbf{9}$ \\
\hline Sundamys muelleri & 0 & 0 & 5 & $\mathbf{5}$ \\
\hline Rattus rattus diardii & 3 & 0 & 0 & $\mathbf{3}$ \\
\hline Callosciurus notatus & 0 & 2 & 0 & $\mathbf{2}$ \\
\hline Maxomys whiteheadi & 1 & 0 & 0 & $\mathbf{1}$ \\
\hline Total & 16 & 36 & 42 & 94 \\
\hline Diversity & 0.7029 & 0.5503 & 0.6948 &
\end{tabular}


approached an asymptote, indicating the sampling relatively covered all species present (Figure 2).

From the 94 individuals captured, 15 individuals from 3 species (16\% prevalence) were infested with ticks. Table 3 lists the number of small mammal individuals captured and the number of individuals infested with ticks and mites (with \% prevalence). R. tiomanicus has the highest rate of ectoparasite infestation, with 12 individuals infested (12.8\% prevalence), followed by $S$. muelleri $(\mathrm{n}=2,2.1 \%)$, and Rattus rattus diardii $(\mathrm{n}=1,1.1 \%)$. On the other hand, 22 individuals from 4 species were infested with mites $(23.4 \%)$. Similar to ticks, the highest small mammal species infested with mites was $R$. tiomanicus $(\mathrm{n}=18$, $19.1 \%$ ), followed by $S$. muelleri $(\mathrm{n}=2,2.1 \%$ ), while Rattus rattus diardii and $M$. whiteheadi shared a similar prevalence percentage $(n=1,1.1 \%)$. All the infested hosts belonged to the same family, Muridae. On the other hand, T. glis and C. notatus were not infested with either ticks or mites, while three individuals of $R$. tiomanicus and one individual of Rattus rattus diardii were infested by both ticks and mites. Although ectoparasite infestation was not significantly different between host $\operatorname{sex}(p>0.05)$, female hosts exhibit higher infestation than male hosts. Table 4 shows the distribution of male and female small mammals infested by both ticks and mites across the study sites.

Table 3. Number of small mammals infested by ticks and mites and their prevalence (\%) in all study sites.

\begin{tabular}{|c|c|c|c|c|c|}
\hline Order & Family & $\begin{array}{l}\text { Small mammal } \\
\text { species }\end{array}$ & $\begin{array}{l}\text { Number of } \\
\text { individuals }\end{array}$ & $\begin{array}{l}\text { Number of } \\
\text { hosts infested } \\
\text { by ticks (\%) }\end{array}$ & $\begin{array}{l}\text { Number of } \\
\text { hosts infested } \\
\text { by mites (\%) }\end{array}$ \\
\hline Rodentia & Muridae & $\begin{array}{l}\text { Rattus tiomanicus } \\
\text { Sundamys muelleri } \\
\text { Rattus rattus diardii } \\
\text { Maxomys whiteheadi }\end{array}$ & $\begin{array}{c}74 \\
5 \\
3 \\
1\end{array}$ & $\begin{array}{c}29 / 12(12.8) \\
8 / 2(2.1) \\
1 / 1(1.1) \\
0(0)\end{array}$ & $\begin{array}{c}46 / 18(19.1) \\
7 / 2(2.1) \\
1 / 1(1.1) \\
6 / 1(1.1)\end{array}$ \\
\hline & Sciuridae & Callosciurus notatus & 2 & $0(0)$ & $0(0)$ \\
\hline Scandetia & Tupaiidae & $\begin{array}{l}\text { Tupaia glis } \\
\text { Total }\end{array}$ & $\begin{array}{c}9 \\
94\end{array}$ & $\begin{array}{c}0(0) \\
38 / 15(16)\end{array}$ & $\begin{array}{c}0(0) \\
60 / 22(23.4)\end{array}$ \\
\hline
\end{tabular}

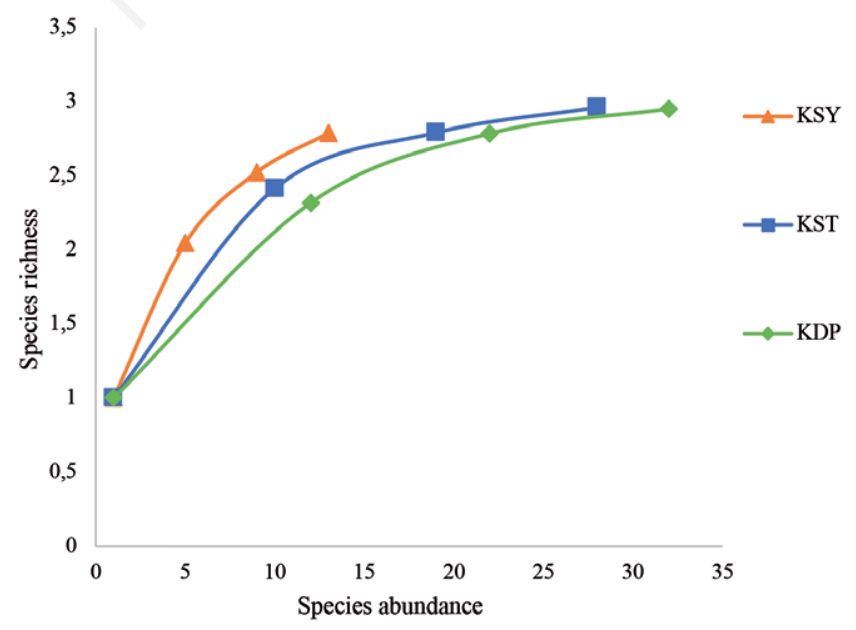

Figure 2. Rarefaction curve of small mammals in all study sites. 


\section{Morphological and molecular identification of ectoparasite samples}

A total of 60 mites and 38 ticks were collected from the 33 infested small mammals belonging to 4 host species. From the stereomicroscopic examination, four tick species were identified, i.e., Ixodes granulatus Supino, 1897, Dermacentor sp., Haemaphysalis sp., and Amblyomma sp., according to their morphology and external characteristics. The amplified DNA sequence of ectoparasites species on 16S rRNA genes were approximately $460 \mathrm{bp}$ in length. The similarity of the genes with the available sequence in the NCBI GenBank and the newly generated GenBank accession numbers are provided in Table 5. The

Table 4. Number of male and female hosts, and their infestation rate of ticks and mites.

\begin{tabular}{lcccc} 
Ectoparasites & Male host & Male infested (\%) & Female hosts & Female infested $(\%)$ \\
Ticks & \multirow{2}{*}{51} & $6(6.4)$ & 43 & $7(7.4)$ \\
Mites & $10(10.6)$ & $43(12.8)$ \\
\hline Total & $16(17.0)$ & & $19(20.2)$ \\
\hline
\end{tabular}

Table 5. List of representative ectoparasite sequences with their host species, BLAST results and newly generated accession numbers from the GenBank.

\begin{tabular}{|c|c|c|c|c|c|}
\hline \multirow{2}{*}{$\begin{array}{l}\text { ID code } \\
\text { (sample) }\end{array}$} & \multirow[t]{2}{*}{ Host species } & \multicolumn{2}{|c|}{ Species (Identification) } & \multirow{2}{*}{$\begin{array}{c}\text { Similarity } \\
\text { with } \\
\text { GenBank, \% }\end{array}$} & \multirow{2}{*}{$\begin{array}{l}\text { Accesion } \\
\text { number }\end{array}$} \\
\hline & & Morphology & Gen & & \\
\hline STM005-02 & R. tiomanicus & Amblyomma sp. & A. cordiferum & 97 & MT912952 \\
\hline STM009-02 & R. tiomanicus & Amblyomma sp. & A. cordiferum & 98 & MT912961 \\
\hline STM010-03 & R. tiomanicus & Amblyomma sp. & A. cordiferum & 98 & MT912962 \\
\hline STM021-01 & R. tiomanicus & Amblyomma sp. & A. cordiferum & 98 & MT912964 \\
\hline STM021-03 & R. tiomanicus & Amblyomma sp. & A. cordiferum & 98 & MT912965 \\
\hline STM021-04 & R. tiomanicus & Amblyomma sp. & A. cordiferum & 98 & MT912966 \\
\hline STM021-06 & R. tiomanicus & Amblyomma sp. & A. cordiferum & 98 & MT912967 \\
\hline KDM032-01 & R. tiomanicus & Amblyomma sp. & A. cordiferum & 98 & MT912980 \\
\hline KDM037-01 & S. muelleri & Amblyomma sp. & A. cordiferum & 98 & MT912981 \\
\hline KDM037-06 & S. muelleri & Amblyomma sp. & A. cordiferum & 97 & MT912986 \\
\hline STM016-01 & R. tiomanicus & Haemaphysalis sp. & H. hystricis & 98 & MT912970 \\
\hline PKY016-03 & R. tiomanicus & Dermacentor sp. & D. auratus & 99 & MT914183 \\
\hline PKY016-04 & R. tiomanicus & Dermacentor sp. & D. auratus & 98 & MT914184 \\
\hline STM010-04 & R. tiomanicus & Dermacentor sp. & D. atrosignatus & 99 & MT912973 \\
\hline STM010-05 & R. tiomanicus & Dermacentor sp. & D. atrosignatus & 99 & MT912974 \\
\hline STM012-01 & R. tiomanicus & Dermacentor sp. & D. atrosignatus & 98 & MT912975 \\
\hline STM012-02 & R. tiomanicus & Dermacentor sp. & D. atrosignatus & 98 & MT912976 \\
\hline PKY002-01 & Rattus rattus diardii & Ixodes sp. & I. granulatus & 98 & MT914179 \\
\hline PKY003-01 & R. tiomanicus & Ixodes sp. & I. granulatus & 98 & MT914180 \\
\hline STM023-01 & R. tiomanicus & L. echidninus & Androlaelaps casalis & 89 & MT808284 \\
\hline STM033-01 & R. tiomanicus & L. echidninus & Androlaelaps casalis & 88 & MT808284 \\
\hline KDM001-01 & R. tiomanicus & L. echidninus & Androlaelaps casalis & 87 & MT808284 \\
\hline KDM015-01 & R. tiomanicus & L. echidninus & Androlaelaps casalis & 88 & MT808284 \\
\hline KDM016-01 & R. tiomanicus & L. echidninus & Androlaelaps casalis & 87 & MT808284 \\
\hline KDM018-01 & R. tiomanicus & L. echidninus & Androlaelaps casalis & 88 & MT808284 \\
\hline KDM020-01 & R. tiomanicus & L. echidninus & Androlaelaps casalis & 88 & MT808284 \\
\hline
\end{tabular}


BLAST search result revealed 5 tick species, namely I. granulatus $(\mathrm{n}=2)$, Dermacentor auratus Supino, 1897 ( $\mathrm{n}=4)$, Dermacentor atrosignatus Neumann, $1906(\mathrm{n}=5)$, Amblyomma cordiferum Neumann, 1899 ( $\mathrm{n}=26)$, and Haemaphysalis hystricis Supino, $1897(\mathrm{n}=1)$. The external morphological characteristic of mite species was first observed and identified under the stereomicroscope as Laelaps sp. based on published taxonomic keys, and further identified as L. echidninus after confirmation with the mite expert, Dr John McGarry (personal communication). However, BLAST results showed that the mite samples were $A n$ drolaelaps casalis (Berlese, 1887) through molecular identification on 16S rRNA genes, but with low per cent similarity value between DNA sequences and the closest match in GenBank ( $87 \%$ to $89 \%)$. We concluded that the species of mite found in small mammal host is recognised as L. echidninus based on their specific morphological features and a large number of this species have been recorded infecting small mammal hosts, according to previous studies (Montasser 2006; Baak-Baak et al. 2016).

From 38 individual tick samples, 19 DNA sequences of $16 \mathrm{~S}$ rDNA genes from the present study were selected for phylogenetic analysis based on the Kimura two-parameter model (K2). In general, the per cent similarity between tick sequences and the closest match in NCBI GenBank is between $97-99 \%$ (Table 5). NJ trees are based on DNA sequences of partial 16S rDNA genes on ticks, as shown in Figure 3. The figure shows the construction

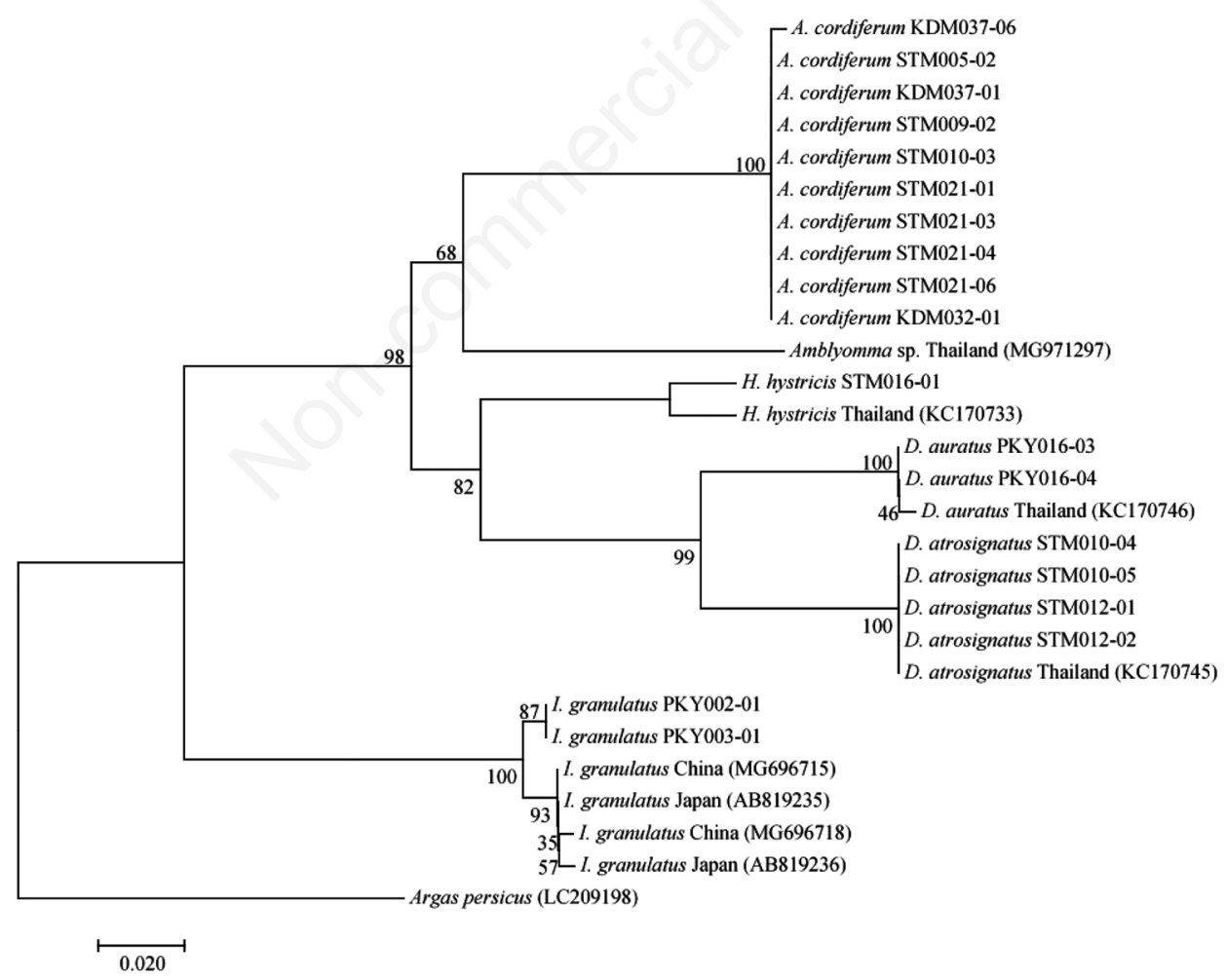

Figure 3. Phylogenetic relationships of 19 mitochondrial 16S rDNA genes of Amblyomma sp., Haemaphysalis sp., Dermacentor sp., and Ixodes sp., rooted with the reference sequences (including 1 outgroup (Argas persicus) available in the GenBank. The tree was constructed and analysed with the neighbour-joining method with 1000 bootstrap replications. 
of different major clades of tick species, i.e., I. granulatus, A. cordiferum, D. auratus, D. atrosignatus, and H. hystricis. In this analysis, Argas persicus is used as an outgroup and was highly separated from the other five major clades.

All $A$. cordiferum ticks from this study are grouped in the same clade, separated from ticks of the Amblyomma sp. from Thailand (bootstrap value =70\%). H. hystricis, STM016-01 is clustered together with $H$. hystricis from Thailand (bootstrap value $=100 \%$ ), whereby $D$. atrosignatus samples are grouped in the same clade with $D$. atrosignatus from Thailand (bootstrap value $=100 \%)$. Both D. auratus sequences (PKY016-03 and PKY016-04) are clustered together in the same clade, but are distantly grouped with $D$. auratus from Thailand (bootstrap value $=46 \%$ ), corresponding to a lower per cent identity from sequence similarity comparison. Moreover, both I. granulatus ticks (PKY002-01 and PKY003-01) formed a monophyletic clade separate from the I. granulatus ticks from Japan and China (bootstrap value $=100 \%$ ). Pairwise distance analysis and comparison of $A$. cordiferum ticks show that the local species is genetically different from Amblyomma sp. from Thailand (0.15\%). No significant difference in genetic distance is observed between H. hystricis in this study and H. hystricis from Thailand. Meanwhile, I. granulatus ticks are slightly different in the genetic distance value ranging between $0.01 \%$ to $0.02 \%$ compared to I. granulatus from China and Japan.

Ten individual mite samples from different hosts were chosen for the phylogenetic analysis. The partial 16S rDNA showed only $87 \%-89 \%$ similarities to existing mite sequences (A. casalis) in the NCBI GenBank (Table 5). NJ tree was generated using sequences of mite samples compared to other reference sequences. Pairwise sequence comparison of all $A$. casalis in this study showed intraspecific variation from $0 \%$ to $0.01 \%$ for partial 16S rDNA genes sequences. These species were close to Gigantolaelaps wolffosohni Fonseca, 1939 (HM059822) isolated from Brazil. Unfortunately, we could not obtain the sequence of Laelaps sp. and made a comparison with that species due to the lack of data in the GenBank database. Thus, the outcome of this analysis could not be extended due to the lack of mites' species validation from other molecular studies.

\section{The intensity of ectoparasite infestation from different host species}

From the five-tick species identified, A. cordiferum ( $\mathrm{n}=26)$ is the most common and abundant tick species infesting two small mammal species, $R$. tiomanicus and $S$. muelleri (Table 6). Meanwhile, only one individual of $H$. hystricis is found infesting $R$. tiomanicus. In addition, one individual of $R$. tiomanicus is found co-infested with Dermacentor cordiferum and A. cordiferum. L. echidninus $(\mathrm{n}=60)$ is found in 4 out of 6 infested small mammal species from all mangrove sites. The most mites collected infested $R$. tiomanicus $(\mathrm{n}=46)$, and only one individual species of L. echidninus is collected from Rattus rattus diardii.

Table 6. Ectoparasite species load in different host species at each study site.

\begin{tabular}{|c|c|c|c|c|c|c|}
\hline $\begin{array}{c}\text { Total tick } \\
\text { load }\end{array}$ & granulatus & $\begin{array}{c}\text { D. } \\
\text { auratus }\end{array}$ & $\begin{array}{c}\text { Ticks } \\
\text { D. } \\
\text { atrosignatus }\end{array}$ & $\begin{array}{c}\text { H. } \\
\text { hystricis }\end{array}$ & $\begin{array}{c}\text { A. } \\
\text { cordiferum }\end{array}$ & $\begin{array}{c}\text { Mites } \\
\text { L. } \\
\text { echidninus }\end{array}$ \\
\hline Rattus tiomanicus 29 & 1 & 4 & 5 & 1 & 18 & 46 \\
\hline Rattus rattus diardii 1 & 1 & 0 & 0 & 0 & 0 & 1 \\
\hline Maxomys whiteheadi 0 & 0 & 0 & 0 & 0 & 0 & 6 \\
\hline Sundamys muelleri 8 & 0 & 0 & 0 & 0 & 8 & 7 \\
\hline Total & 2 & 4 & 5 & 1 & 26 & 60 \\
\hline
\end{tabular}




\section{Discussion}

In this study, we present the diversity of small mammal inhabitants and the prevalence of ectoparasites in three mangroves areas in Peninsular Malaysia; Kg. Sg. Yak Yah, Terengganu (KSY); Kg. Dew, Perak (KDP), and Kg. Sg. Timun, Negeri Sembilan (KST). The ectoparasite microscopic identification was also validated through genetic analyses, including the construction of phylogenetic trees to recognise the phylogenetic relationships between each group of ectoparasites species. Six species of small mammals were captured from all study sites, dominated by $R$. tiomanicus. From this number, three host species were infested by ticks and mites ( $R$. tiomanicus, Rattus rattus diardii, and $S$. muelleri), whereas $M$. whiteheadi was only infested with mites. These small mammals were hosts to five tick species (I. granulatus, D. auratus, D. atrosignatus, A. cordiferum, and $H$. hystricis), and one mite species (L. echidninus). Among these ectoparasites, L. echidninus mite and A. cordiferum tick were highly prevalent among the small mammals.

Overall, the diversity of small mammals in the mangrove forests was relatively poor (Shannon index of $<1.0$ ), compared to lowland (Yusof et al. 2019) and highland (Shukor et al. 2001) forests in the Malaysian region. From this study, the least diverse small mammals were recorded at KST, which corresponded to the higher level of anthropogenic pressure, as indicated in Mohd-Taib et al. (2020). This finding is parallel with Carugati et al. (2018), who stated that the diversity of fauna was significantly lesser in disturbed habitats, due to their extreme conditions (irradiation and high temperature) and anthropogenic disturbances. In addition, Friggens and Beier (2010) and Young et al. (2015) implied that the ectoparasite prevalence among small mammal hosts was associated with the intensity of habitat disturbance, where high host diversity and low levels of anthropogenic disturbances led to a lower intensity of ectoparasite prevalence. In contrast, our study did not show a correlation between parasite prevalence and anthropogenic disturbances. Other environmental factors like the rainfall that led to flooding may suppress the development of ectoparasites and their larvae (Krasnov et al. 2001), subsequently reducing the prevalence of ectoparasites. On the other hand, incidental effects of the environment on ectoparasites involved changes in host behaviour (grooming rates, burrowing behaviour, physiology, and community density; Young et al. 2015), which may influence the ectoparasites community. However, the growing adaptability of the host population in exploiting the areas with high anthropogenic disturbance may facilitate the transmission of ectoparasite (Pearce and O’Shea 2007).

Unlike the four infested species that belong to the family Muridae, two species were not infested by any ectoparasites, namely $T$. glis and $C$. notatus from the families Tupaiidae and Sciuridae. Similar to Madinah et al. (2014) and Ishak et al. (2018b), these species exhibited a significantly low number of ectoparasite loads compared to Muridae. Rodents from the family Sciuridae are tree-top squirrel and spent most of the time on tree canopies, instead of on the ground (Thanee et al. 2009). Thus, the chance of getting infested with ectoparasite, especially in the nymph stage and contact with other mammal hosts are lower, resulting in a low infestation rate (Nicholson et al. 2019). Meanwhile, the lack of ectoparasite loads on $T$. glis (ground squirrel) could be due to high frequency of grooming activities, which was established as the most effective way in reducing the prevalence of ectoparasite on this species (Sulaiman et al. 2016). Moreover, Maaz et al. (2018) stated that the absence of ectoparasites on host species could be due to the survival of ectoparasite itself in the surrounding, low rate of infestation, and low host specificity. On another note, there were no records of other ectoparasites, such as flea or louse present in all small mammals captured in this habitat, which concurs with other previous studies of Salleh et al. 
(2003) and Paramasvaran et al. (2009). We suggest that the dynamics of host-parasite relations, including host immunity on parasite fitness and host preferences, contribute to the absence of these ectoparasites. In addition, some ectoparasites like flea and louse, which are often associated with hosts, are living selectively in specific resting sites with different nest and burrows environment (Sparagano et al. 1999; Razali et al. 2018) and the tendency to develop well in warmer surroundings (Krasnov et al. 2001).

Rattus tiomanicus, a highly abundant species captured in our study, exhibited a high prevalence of ticks and mites' infestation. This could be due to social and behavioural aspects of the hosts, which include social group size, and home range that covers riparian habitat (Ng et al. 2017). This species is nocturnal and often found in typical habitats (primary and secondary forest), including coastal forest (Payne et al. 1985). It is also known as a commensal, as they also inhabit human habitation (Harrison 1957). Besides that, this species is recognised as the predominant domestic pest in an agricultural area (Medway 1983) and build spherical nests in recesses of tree stumps in which they directly tend to harbour a high abundance of ectoparasite species from the vegetation (MohamedHassan et al. 2012; Kim et al. 2013). The ecology and distribution of R. tiomanicus encompassed the Indonesian island of Sumatra, southern Thailand (Wood 1972), and was reportedly widespread throughout Peninsular Malaysia as early as the 1930s (Wood and Chung 2003). Lim et al. (1977) related the foraging and omnivorous behaviour of commensal rats, contributing to their pervasive infection. Mariana et al. (2005) reported six tick species, including Haemaphysalis spp., Dermacentor spp., and Ixodes spp., and two species of mites (Laelaps echidninus and Laelaps nuttali Hirst, 1915) collected on-host of $R$. tiomanicus from Gunung Stong forest reserve, Kedah, Malaysia. Furthermore, Ng et al. (2017) also documented multiple infections of ectoparasite species (Haemaphysalis sp., Laelaps spp., and chiggers) on $R$. tiomanicus from residential areas in western Sarawak.

The number of male hosts collected in all mangrove sites was higher than female hosts. Kowalski et al. (2015) mentioned that males of various small mammal species move over longer distances and significantly farther than females host, increasing the chance of getting captured in traps. However, female hosts harboured twice the number of ectoparasites compared to the male species. Females of several small mammal species typically solitarily nurse their offspring, which eases the vertical spreading of ectoparasites to their juveniles (Yamamura 1993; Ebert and Herre 1996). Gorrell and Schulte-Hostedde (2008) strongly demonstrated that the ectoparasites (females) lay their eggs in the host nest, directly consuming a higher nutritional resource than a solitary male nest. Therefore, it may reveal higher ectoparasite infestation levels on female individuals host than male hosts. However, the findings contradicted the later studies of Kowalski et al. (2015) and Ishak et al. (2018b), where the infestation rate of ectoparasites on male hosts was higher than females of small mammals. Bantihun and Bekele (2015) reported that males often have a more extensive home range and can travel further, therefore, easily exposed to ectoparasites than females. Differences in host body mass, movement patterns, spatial behaviour, and minor immunocompetence of males could provide a greater variety of niches for ectoparasites infestation, as they can withstand a higher number of arthropods (Balashov et al. 2007). Our study showed no record of male tick species, as mentioned by Durden et al. (2018) that they naturally do not feed on host skin.

Few studies have examined the morphological and molecular characteristics of arthropods, particularly ticks and mites (Chuluun et al. 2005; Paramasvaran et al. 2009; Madinah et al. 2011; Sponchiado et al. 2015; Ernieenor et al. 2016; Ishak et al. 2018a). According 
to their external features, tick species are more likely to be recognised and identified based on specific published taxonomic keys up to the species level. Mite observation under the stereomicroscope, on the other hand, is more challenging due to their tiny size, the lack of taxonomic keys, and the fact that the information of mite species is scarce and outdated. Based on the morphological and physical characteristics of the reference keys (Baker 1999), the mite species was initially identified as Laelaps sp., which was then confirmed to be $L$. echidninus. This species is occasionally found in rodents and as a parasite of the Norway rat (brown rat), R. norvegicus (Montasser 2006; Baak-Baak et al. 2016). Besides that, the study on L. echidninus was vital and primarily concerned investigations of host-parasite relationships (Soliman et al. 2001). Nevertheless, according to the BLAST results obtained, the gene similarity of the mite sequences was matched to $A$. casalis, with low per cent similarity value through molecular identification on $16 \mathrm{~S}$ rRNA genes. The low per cent similarity value could be due to the lack of studies and reference sequence in the GenBank database using partial 16S rDNA genes. Thus, we suggest using other target markers, such as 28S and 18S rDNA genes (Machida and Knowlton 2015) for identifying mite samples at specific DNA region for future complementary analysis. This was supported by Matsuda et al. (2014) and Famah Sourassou et al. (2015), as the genes of nuclear ribosomal DNA have been considered valuable for determining high phylogeny level of mite species. Meanwhile, a total of five different tick species were identified up to the genus level (Ixodes sp., Amblyomma sp., Dermacentor sp., and Haemaphysalis sp.). Other than that, the DNA sequences belonging to all tick species presented high similarity values of about $97 \%-99 \%$ through the BLAST search. The results from this study further established the achievement of molecular data of tick species through DNA barcoding for this region, including Southeast Asia.

Our study indicates that the genetic characterisation is concurrent with the geographical distribution of each ectoparasite species. Haemaphysalis hystricis, Dermacentor auratus, and Dermacentor atrosignatus are grouped with the same species in Thailand. The findings proved that tick species from different Southeast Asian countries shared the same genetic clade. Ixodes granulatus formed a monophyletic clade with the same species from Japan and China. Meanwhile, A. cordiferum tick was distantly separated from Amblyomma sp. of Thailand, which concluded that there were some differences in genetic identity between them. H. hystricis ticks have also been occasionally found from barking deer and wild boar (Petney et al. 2019), while their nymphs have been collected from the black rat, R. rattus, and the Asian palm and civet squirrels (Khoo et al. 2016; Petney et al. 2019). The nymph stage of $D$. auratus is commonly found on small to medium mammals, other rodents, porcupine, wild hens, and monkeys (Hoogstraal and Wassef 1985). In addition, D. atrosignatus is also found in wild pigs, reptiles, and mammals (Mariana et al. 2005). All ticks from the genus Dermacentor are a likely vector to zoonotic diseases, such as the Lanjan virus (Karabatsos 1985). I. granulatus infested small mammals, especially rodents in Peninsular Malaysia (Ernieenor et al. 2016; Madinah et al. 2011; Ishak et al. 2018b). The larvae or immature stages of $A$. cordiferum tick feed on small mammals (Barnard and Durden 2000), and this tick prefers to feed on ophidian hosts during the adult stage (Ho and Ismail 1984). On the other hand, little is known about the mite of small mammals in Peninsular Malaysia; thus, it is often underestimated. Laelapidae mites were reported as obligate or facultative parasites in small mammal nests in various habitats (Martins-Hatano et al. 2011). Our findings revealed that the mite load was much higher than that of the tick, as mites were frequently found infesting commensal wild rodents at night, in their nests (Mullen and O’Connor 2002). Klein et al. (2018) mentioned that host's nests provide food and nutri- 
tional supply to parasitic mites through excretions and scabs of the hosts, incidentally facilitating dispersal to other nests, as well as increasing the number of mite infestation among hosts. Besides, the fruiting season might induce mite infestation among rodent hosts due to increasing resource accessibility (Wells et al. 2014). L. echidninus is also frequently found in rodents such as Rattus sp., as reported in Mexico (Baak-baak et al. 2016), and capable of transmitting the Junin virus and lethal apicomplexan protozoan to animals, especially rats (McLay et al. 2014). In short, small mammals associated with ectoparasites, especially ticks, act as a vector to many zoonotic pathogens, like the spotted fever group Rickettsia, Bartonella spp., Borrelia burgdorferi, Ehrlichia spp., and tick-borne encephalitis virus (Comer et al. 2001). Rodents living near human population act as a vital reservoir in spreading vector-borne diseases to humans and animals (Meerburg et al. 2009). Krasnov et al. (2004) described that the diversity of small mammal hosts in a habitat could also be crucial in defining the species richness of ticks and mites instead of the intrinsic influences (body size of the host).

\section{Conclusions}

The low diversity of small mammals in the mangrove ecosystem were heavily infested with ectoparasites, including ticks and mites. The development of each life-stage of these ectoparasites was dependent on the habitat quality and their countless hosts (Maaz et al. 2018). Validation for each ectoparasite species from both morphological and molecular approaches should be improved and refined to avoid misinterpretation of the information. Besides, the total prevalence of small mammals infested by mites was higher than ticks at all study sites. It indicates that mites colonised a greater niche range in mangrove forests. The study of ectoparasites in small mammals remains preliminary, with a further assessment about the exposure yet to be explored. Besides, small mammals are reportedly important hosts for the immature development of the most imperative vectorborne pathogens in many countries over the world (Klein et al. 2018). Ectoparasite-borne disease investigation can offer a picture of the relative abundance and diversity of small mammal inhabitants, as well as their important epidemiologic data on the host preference and distribution of associated ectoparasites. Further surveillances of the ectoparasitehost relationships are essential to better understand the dynamics of their population and distributions, the prevalence of arthropod-borne pathogens, and their potential transmission, including health risk in areas close to human settlements and nearby attraction areas. Apart from that, a comprehensive investigation on ecological requirements of ectoparasites, the intensity of small mammal-associated ectoparasites on wild rodents, and how they could colonise an anthropologically disturbed area close to people, need to be addressed in future studies.

\section{Acknowledgements}

This project was supported in part by the Tenaga National Berhad Research (TNBR) Sdn. Bhd. for providing funds under the Research Grant ST-2018-008. We want to express our gratitude to Dr Ben Makepeace and Dr John McGarry from the University of Liverpool, United Kingdom (UK) for their help and guidance on species identification and verification of mite samples. We would also like to extend our appreciation to the state agencies permitting the research work in the mangrove areas, field assistants and members of the Wildlife Disease and Ecology Research group (WildDER), Universiti Kebangsaan Malaysia. 


\section{Contributions}

FSM-T, RA and SMN conceived and designed the study; RA collected data; FSM-T and RA did the analysis, interpreted the results and prepared the draft manuscript. All authors reviewed the results and approved the final version of the manuscript.

\section{Conflict of interest}

The authors declare that they have no conflict of interest.

\section{References}

Akucewich LH, Philman K, Clark A, Gillespie J, Kunkle G, Nicklin CF, Greiner EC. 2002. Prevalence of ectoparasites in a population of feral cats from north central Florida during the summer. Veteterinary Parasitology. 109(1-2):129-139. http://dx.doi.org/10.1016/s0304-4017(02)00205-4.

Ashton EC, Macintosh DJ. 2002. Preliminary assessment of the plant diversity and community ecology of the Sematan mangrove forest, Sarawak, Malaysia. Forest Ecology and Management. 166(13):111-129. http://dx.doi.org/10.1016/S0378-1127(01)00673-9

Baak-Baak CM, Cigarroa-Toledo N, Torres-Chablé OM, Arana-Guardía R, Puerto FI, MachainWilliams C, García-Rejón JE. 2016. New records of ectoparasites Echinolaelaps echidninus and Polyplax spinulosa on rodents with serological evidence of flavivirus infections at Mérida, Yucatán, México. Southwestern Entomologist. 41(1):75-85. https://doi.org/10.3958/059.041.0109

Baker AS. 1999. Mites and ticks of domestic animals. An identification guide and information source. London: The Stationery Office. 240 pp.

Balashov YS, Bochkov AV, Vashchenok VS, Grigor'eva LA, Stanyukovich MK, Tret'yakov KA. 2007. Segregation of ectoparasitic communities of small forest mammals among ecological niches. Doklady Biological Sciences. 415:280-283. https://doi.org/10.1134/S0012496607040096

Balete DS, Heaney LR, Josefa Veluz M, Rickart EA. 2009. Diversity patterns of small mammals in the Zambales Mts., Luzon, Philippines. Mammalian Biology. 74(6):456-466. https://doi.org/10.1016/j. mambio.2008.05.006

Bantihun G, Bekele A. 2015. Diversity and habitat association of small mammals in Aridtsy forest, Awi Zone, Ethiopia. Zoological Research. 36(2):88-94. https://doi.org/10.13918/j.issn.20958137.2015.2.88

Barbier EB, Strand I. 1998. Valuing mangrove-fishery linkages. Environmental and Resource Economics. 12(2):151-166. https://doi.org/10.1023/A:1008248003520

Barnard SM, Durden LA. 2000. A veterinary guide to the parasites of reptiles. Vol. 2. Arthropods (excluding mites). Krieger Press. Melbourne. 298 pp.

Bernard H, Mohd Yusah K, Yasuma S, Kimsui L. 2004. A survey of the non-flying small mammals at several elevations and around Crocker Range Park. Crocker Range Scientific Expedition 2002. $268 \mathrm{pp}$.

Black WC, Piesman J. 1994. Phylogeny of hard and soft tick taxa (Acari: Ixodida) based on mitochondrial 16S rDNA sequences. Proceedings of the National Academy of Sciences of the United States of America. 91(21):10034-10038. https://doi.org/10.1073/pnas.91.21.10034

Carpi G, Cagnacci F, Wittekindt NE, Zhao F, Qi J, Tomsho LP, Drautz DI, Rizzoli A, Schuster SC. 2011. Metagenomic profile of the bacterial communities associated with Ixodes ricinus ticks. PLoS ONE. 6:e25604. https://doi.org/10.1371/journal.pone.0025604

Carugati L, Gatto B, Rastelli E, Martire ML, Coral C, Greco S, Danovaro R. 2018. Impact of mangrove forests degradation on biodiversity and ecosystem functioning. Scientific Reports. 8:13298. https://doi.org/10.1038/s41598-018-31683-0

Chong VC. 2006. Sustainable utilisation and management of mangrove ecosystems of Malaysia. Aquatic Ecosystem Health and Management. 9(2):249-260. https://doi.org/10.1080/ 14634980600717084

Chuluun B, Mariana A, Ho T, Mohd Kulaimi B. 2005. A preliminary survey of ectoparasites of small 
mammals in Kuala Selangor Nature Park. Tropical Biomedicine. 22:243-247. PMID: 16883294

Comer JA, Paddock CD, Childs JE. 2001. Urban zoonoses caused by Bartonella, Coxiella, Ehrlichia, and Rickettsia species. Journal of Vector-Borne and Zoonotic Diseases. 1(2):91-118. https://doi. org/10.1089/153036601316977714

de la Fuente J, Estrada-Peña A, Cabezas-Cruz A, Kocan KM. 2016. Anaplasma phagocytophilum uses common strategies for infection of ticks and vertebrate hosts. Trends in Microbiology. 24(3):173180. https://doi.org/10.1016/j.tim.2015.12.001

Dobec M, Golubic D, Punda-Polic V, Kaeppeli F, Sievers M. 2009. Rickettsia helvetica in Dermacentor reticulatus ticks. Emerging infectious Diseases. 15(1):98-100. https://doi.org/10.3201/eid1501. 080815

Dobson ADM, Auld S. 2016. Epidemiological implications of host biodiversity and vector biology: key insights from simple models. American Naturalist. 187:405-422. https://doi.org/10.1086/ 685445

Durden LA, Kessler SE, Radespiel U, Zimmermann E, Hasiniaina AF, Zohdy S. 2018. A new species of sucking louse (Phthiraptera: Anoplura: Polyplacidae) from the Gray Mouse Lemur, Microcebus murinus (Primates: Cheirogaleidae), in Madagascar. Journal of Medical Entomology. 55(4):910 914. https://doi.org/10.1093/jme/tjy046

Ebert D, Herre EA. 1996. The evolution of parasitic diseases. Parasitology Today. 12:96-101. https://doi.org/10.1016/0169-4758(96)80668-5

Entsminger GL. 2012. EcoSim Professional: Null modelling software for ecologists, Version 1, Montrose, CO: Acquired Intelligence Inc., Kesey-Bear, and Pinyon Publishing. Available from: http://www.garyentsminger.com/ecosim/index.html

Ernieenor FCL, Yaakop S, Ahamad M, George E, Md Nor S. 2016. Precise identification of different stages of a tick, Ixodes granulatus Supino, 1897 (Acari: Ixodidae). Asian Pacific Journal of Tropical Biomedicine. 6(7):597-604. http://doi.org/10.1016/j.apjtb.2016.05.003

Eslami A, Yousefi A, Dowling APG. 2018. Prevalence of ectoparasites in black rat (Rattus rattus) from Mangrove forests of Qeshm Island, Iran. Comparative Clinical Pathology. 27:1583-1592. https://doi.org/10.1007/s00580-018-2777-3

Estrada-Peña A, de la Fuente J. 2014. The ecology of ticks and epidemiology of tick-borne viral diseases. Antiviral Research. 108(1):104-128. https://doi.org/10.1016/j.antiviral.2014.05.016

Famah Sourassou N., de Moraes GJ, Delalibera Júnior I, Soares Corrêa A. 2015. Phylogenetic analysis of Ascidae sensu lato and related groups (Acari: Mesostigmata: Gamasina) based on nuclear ribosomal DNA partial sequences. Systematic and Applied Acarology. 20(3):225. https://doi.org/10. 11158/saa.20.3.1

Francis CM. 2008. A field guide to the mammals of South-East Asia. London (UK): New Holland Publishers. $392 \mathrm{pp}$.

Friggens MM, Beier P. 2010. Anthropogenic disturbance and the risk of flea-borne disease transmission. Oecologia. 164:809-820. https://doi.org/10.1007/s00442-010-1747-5

Gorrell JC, Schulte-Hostedde AI. 2008. Patterns of parasitism and body size in red squirrels (Tamiasciurus hudsonicus). Canadian Journal of Zoology. 86(2):99-107. https://doi.org/10.1139/Z07-123

Haddad V, Haddad MR, Santos M, Cardoso J. 2018. Skin manifestations of tick bites in humans. Anais Brasileiros de Dermatologia. 93(2):251-255. https://doi.org/10.1590/abd1806-4841. 20186378

Harrison JL. 1957. Habitat of some Malayan rats. Proceedings of the Zoological Society of London. 128:1-21. https://doi.org/10.1111/j.1096-3642.1957.tb00254.x

Heukelbach J, Frank R, Ariza L, de Sousa Lopes I, de Assis e Silva A, Borges AC, Limongi JE, de Alencar CHM, Klimpel S. 2012. High prevalence of intestinal infections and ectoparasites in dogs, Minas Gerais State (southeast Brazil). Parasitology Research. 111(5):1913-1921. https://doi. org/10.1007/s00436-012-3037-0

Ho TM, Ismail S. 1984. Life cycle of the tick Amblyomma cordiferum Neumann under laboratory conditions. Malayan Nature Journal. 38:73-77.

Hogarth PJ. 2015. The Biology of Mangroves and Seagrasses. New York: Oxford University Press. 1-7 pp.

Hoogstraal H, Wassef HY. 1985. Dermacentor (Indocentor) atrosignatus (Acari: Ixodoidea: Ixodidae): 
hosts and distribution in the Malay Peninsula, Indonesia, Borneo, and southern Philippines. Journal of Medical Entomology. 22:644-647. https://doi.org/10.1093/jmedent/22.6.644

Horak IG, Camicas J-L, Keirans JE. 2002. The Argasidae, Ixodidae and Nuttalliellidae (Acari: Ixodida): a world list of valid tick names. Experimental and Applied Acarology. 28:27-54. https://doi.org/ 10.1023/A:1025381712339

Ishak SN, Lim FS, Mohd-Taib FS, Khoo JJ, Shukor MN, Yusof MA, Mohd-Sah SA, Sitam FT, Japning JRR. 2018a. Molecular identification of hard ticks (Ixodes sp.) infesting rodents in Selangor, Malaysia. AIP Conference Proceedings. 1940:020054. https://doi.org/10.1063/1.5027969

Ishak SN, Yusof MA, Shukor MN, Mohd-Sah SA, Lim FS, Khoo JJ, Mohd-Taib FS. 2018b. Prevalence of on-host ticks (Acari: Ixodidae) in small mammals collected from forest near to human vicinity in Selangor, Malaysia. Systematic and Applied Acarology. 23(8):1531-1544. https://doi.org/ 10.11158/saa.23.8.4

Jekel JF, Katz DL, Elmore JG, Wild DMG. 2001. Epidemiology, biostatistics, and preventive Medicine. $2^{\text {nd }}$ Edition. Philadelphia: WB Saunders.

Jusoff K. 2013. Malaysian mangrove forests and their significance to the coastal marine environment. Polish Journal of environmental Studies. 22(4):979-1005.

Kairo JG, Dahdouh-Guebas F, Bosire J, Koedam N. 2001. Restoration and management of mangrove systems - a lesson for and from the East African region. South African Journal of Botany. 67:383389. https://doi.org/10.1016/S0254-6299(15)31153-4

Karabatsos N. 1985. International catalogue of arboviruses, including certain other viruses of vertebrates. 3rd edition. San Antonio: American Society for Tropical Medicine and Hygiene. With the 1986-1995 Supplements to the International catalogue. CDC Div. Vector-Borne Infect Dis., Ft Collins. 1147 pp.

Kathiresan K. 2000. A review of studies on Pichavaram mangrove, southeast India. Hydrobiologia. 430(1):185-205. https://doi.org/10.1023/A:1004085417093

Kathiresan K, Bingham BL. 2001. Biology of mangroves and mangrove ecosystems. Advances in Marine Biology. 40:81-251. https://doi.org/10.1016/S0065-2881(01)40003-4

Khan MM. 2012. Evolution and biogeography of Malaysian Mammals. Khazanah Mamalia Peninsular Malaysia. Kuala Lumpur: Universiti Malaysia Terengganu (UMT).

Khoo JJ, Fezshin C, Kho L, Ahmad Shanizza AI, Lim FS, Tan KK, Chang LY, AbuBakar S. 2016. Bacterial community in Haemaphysalis ticks of domesticated animals from the Orang Asli communities in Malaysia. Ticks and Tick-Borne Diseases. 7(5):929-937. https://doi.org/10.1016/j.ttbdis. 2016.04.013

Kim HC, Chong ST, NUNN PV, Jang W-J, Klein, TA, Robbins RG. 2013. Seasonal abundance of ticks collected from live-captured small mammals in Gyeonggi Province, Republic of Korea, during 2009. Systematic and Applied Acarology. 18(3):201-211. https://doi.org/10.11158/saa.18.3.1

Klein A, Zimmermann E, Radespiel U, Schaarschmidt F, Springer A, Strube C. 2018. Ectoparasite communities of small-bodied Malagasy primates: seasonal and socioecological influences on tick, mite and lice infestation of Microcebus murinus and M. ravelobensis in northwestern Madagascar. Parasites Vectors. 11(1):459. https://doi.org/10.1186/s13071-018-3034-y

Kowalski K, Bogdziewicz M, Eichert U, Rychlik L. 2015. Sex differences in flea infections among rodent hosts: is there a male bias?. Parasitology Research. 114(1):337-341. 10.1007/s00436014-4231-z

Krasnov BR, Khokhlova IS, Fielden LJ, Burdelova NV. 2001. Development rates of two Xenopsylla flea species in relation to air temperature and humidity. Medical and Veterinary Entomology. 15:249-258.

Krasnov BR, Shenbrot GI, Khokhlova IS, Degen AA. 2004. Flea species richness and parameters of host body, host geography and host 'milieu'. Journal of Animal Ecology. 73:1121-1128. https:// doi.org/10.1111/j.0021-8790.2004.00883.x

Kröber T, Guerin P. 2007. The tick blood meal: from a living animal or from a silicone membrane? ALTEX. 24 (Special issue):39-41. PMID: 19835054.

Kumar S, Stecher G, Tamura K. 2016. MEGA7: Molecular evolutionary genetics analysis version 7.0 for bigger datasets. Molecular Biology and Evolution. 33(7):1870-1874. https://doi.org/10.1093/ molbev/msw054 
Li J, Zheng X, Cai Y, Zhang X, Yang M, Yue B, Li J. 2014. DNA barcoding of Murinae (Rodentia: Muridae) and Arvicolinae (Rodentia: Cricetidae) distributed in China. Molecular Ecology Resources. 15(1):153-167. https://doi.org/10.1111/1755-0998.12279

Lim BL, Yap LF, Krishnasamy M. 1977. Capillaria hepatica infection of wild rodents in Peninsular Malaysia. Southeast Asian Journal of Tropical Medicine and Public Health. 8(3):354-358.

Luther DA, Greenberg R. 2009. Mangroves: a global perspective on the evolution and conservation of their terrestrial vertebrates. BioScience, 59(7):602-612. https://doi.org/10.1525/bio.2009.59.7.11

Maaz D, Krücken J, Blümke J, Richter D, McKay-Demeler J, Matuschka F-R, Hartmann S, SamsonHimmelstjerna GV. 2018. Factors associated with diversity, quantity and zoonotic potential of ectoparasites on urban mice and voles. PLOS ONE. 13(6):e0199385. https://doi.org/10.1371/ journal.pone. 0199385

Machida RJ, Knowlton N. 2015. PCR primers for metazoan nuclear 18S and 28S Ribosomal DNA sequences. PLoS ONE. 10(7):e0134314. https://doi.org/10.1371/journal.pone.0046180

Madinah A, Abang F, Mariana A, Abdullah MT, Mohd-Azian J. 2014. Interaction of ectoparasites-small mammals in tropical rainforest of Malaysia. Community Ecology. 15(1):113-120. https:// doi.org/10.1556/ComEc.15.2014.1.12

Madinah A, Fatimah A, Mariana A, Abdullah MT. 2011. Ectoparasites of small mammals in four localities of wildlife reserves in Peninsular Malaysia. Southeast Asian Journal of Tropical Medicine and Public Health. 42(4):803-813.

Mariana A, Zuraidawati Z, Ho TM, Mohd Kulaimi B, Saleh I, Shukor MN, Shahrul-Anuar MS. 2005. A survey of ectoparasites in Gunung Stong Forest Reserve, Kelantan, Malaysia. The Southeast Asian Journal of Tropical Medicine and Public Health. 5:1125-1131. PMID: 16438136

Martins-Hatano F, Raíces DS, Gazeta GS, Serra-Freire NM, Gettinger D, Bergallo HG. 2011. Community composition of laelapine mites (Acari: Laelapidae) associated with the nests and fur of Cerradomys subflavus (Wagner, 1842). Journal of Natural History. 45(27-28):1679-1688. https://doi.org/10.1080/00222933.2011.559690

Massolo A, Sforzi A, Lovari S. 2003. Chemical immobilisation of crested porcupines with tiletamine $\mathrm{HCl}$ and zolazepam $\mathrm{HCl}$ (Zoletil) under field conditions. Journal of Wildlife Diseases. 39(3):727731. https://doi.org/10.7589/0090-3558-39.3.727

Matsuda T, Morishita M, Hinomoto N, Gotoh T. 2014. Phylogenetic analysis of the spider mite subfamily Tetranychidae (Acari: Tetranychidae) based on the mitochondrial COI and the $18 \mathrm{~S}$ and the 5 'end of the $28 \mathrm{~S}$ genes indicates that several genera are polyphyletic. PLOS ONE. 9(10):e108672. https://doi.org/10.1371/journal.pone.0108672

McLay L, Liang Y, Ly H. 2014. Comparative analysis of disease pathogenesis and molecular mechanisms of New World and Old World arenavirus infections. Journal of General Virology. 95:1-15. https://doi.org/10.1099/vir.0.057000-0

Medway L. 1983. The Wild Mammals of Malaya (Peninsular Malaysia) and Singapore, 2nd edition. Kuala Lumpur: Oxford University Press. 131 pp.

Meerburg BG, Singleton GR, Kijlstra A. 2009. Rodent-borne diseases and their risks for public health. Critical Reviews in Microbiology. 35(3):221-270. https://doi.org/10.1080/10408410902989837

Mohamed-Hassan SN, Bahaman AR, Mutalib AR, Khairani-Bejo S. 2012. Prevalence of pathogenic leptospires in rats from selected locations in Peninsular Malaysia. Scientific Journal of Animal Science. 6:12-25. https://doi.org/10.3923/rjnasci.2012.12.25

Mohd Zain S, Syed Khalil Amdan S, Braima K, Abdul-Aziz N, Wilson J, Sithambaran P, Jeffery J. 2015. Ectoparasites of murids in Peninsular Malaysia and their associated diseases. Parasites Vectors. 8:254. https://doi.org/10.1186/s13071-015-0850-1

Mohd-Taib FS, Mohd-Saleh W, Asyikha R, Mansor MS, Ahmad-Mustapha M, Mustafa-Bakray NA, Mod-Husin S, Md-Shukor A, Amat-Darbis ND, Sulaiman N. 2020. Effects of anthropogenic disturbance on the species assemblages of birds in the back mangrove forests. Wetlands Ecology and Management. 28:479-494. https://doi.org/10.1007/s11273-020-09726-Z

Montasser AA. 2006. The spiny rat mite Echinolaelaps echidninus (Berlese, 1887) (Dermanyssoidea: Laelapidae): redescription of the female with emphasis on its gnathosoma, sense organs, peritreme and pulvilli. International Journal of Zoological Research. 2:1-13. https://doi.org/10.3923/ ijzr.2006.1.13 
Mullen GR, O’Connor BM. 2002. Mites (Acari). In: G.R. Mullen and I. Durden (Eds.), Medical and veterinary entomology. New York: Academic Press. p. 449-516.

Ng YL, Hamdan NES, Tuen AA, Mohd-Azlan J, Chong YL. 2017. Co-infections of ectoparasite species in synanthropic rodents of western Sarawak, Malaysian Borneo. Tropical Biomedicine. 34(3):723-731.

Nicholson WL, Sonenshine DE, Noden BH, Brown RN. 2019. Ticks (Ixodida). In: Mullen GR, Durden LA, editors. Medical and Veterinary Entomology. (Third Edition). New York: Academic Press. p. 603-672. https://doi.org/10.1016/B978-0-12-814043-7.00027-3

Paramasvaran S, Sani RA, Hassan L, Krishnasamy M, Jeffery J, Oothuman P, Santhana RL. 2009. Ectoparasite fauna of rodents and shrews from four habitats in Kuala Lumpur and the states of Selangor and Negeri Sembilan, Malaysia and its public health significance. Tropical Biomedicine. 26(3):303-311.

Payne J, Francis CM, Phillips K. 1985. A field guide to the mammals of Borneo. Kota Kinabalu: Sabah Society. 332 pp.

Pearce RD, O'Shea TJ. 2007. Ectoparasites in an urban population of big brown bats (Eptesicus fuscus) in Colorado. Journal of Parasitology. 93:518-530. https://doi.org/10.1645/ge-973r.1

Petney TN, Saijuntha W, Boulanger N, Chitimia-Dobler L, Pfeffer M, Eamudomkarn C, Andrews RH, Ahamad M, Putthasorn N, Muders SV, et al. 2019. Ticks (Argasidae, Ixodidae) and tick-borne diseases of continental Southeast Asia. Zootaxa. 4558(1):1-89. https://doi.org/10.11646/zootaxa. 4558.1.1

Polidoro BA, Carpenter KE, Collins L, Duke NC, Ellison AM, Ellison JC, Farnsworth EJ, Fernando ES, Kathiresan K, Koedam NE, et al. 2010. The loss of species: mangrove extinction risk and geographic areas of global concern. PLOS ONE. 5(4):e10095. https://doi.org/10.1371/journal.pone.0010095

Pulscher LA, Moore TC, Caddell L, Sukhbaatar L, Fricken ME, Anderson BD, Gonchigoo B, Gray GC. 2018. A cross-sectional study of small mammals for tick-borne pathogen infection in northern Mongolia. Infection Ecology and Epidemiology. 8:1-7. https://doi.org/10.1080/20008686. 2018.1450591

Razali NB, Shamsudin N, Rahaniza AMJ, Yaakop S, Khoo JJ, Mohd-Taib FS. 2018. Ectoparasites (ticks and mites) prevalence on small to medium-sized mammals associated with habitat condition in Kemasul, Pahang. Serangga. 23(1):72-88.

Rickart EA, Heaney LR, Balete DS, Tabaranza BR. 2011. Small mammal diversity along an elevational gradient in northern Luzon, Philippines. Mammalian Biology. 76(1):12-21. https://doi.org/ 10.1016/j.mambio.2010.01.006

Rodkvamtook W, Kuttasingkee N, Linsuwanon P, Sudsawat Y, Richards AL, Somsri M, Sangjun N, Chao CC, Davidson S, Wanja E, Gaywee J. 2018. Scrub typhus outbreak in Chonburi Province, central Thailand, 2013. Emerging infectious Diseases. 24(2):361-365. https://doi.org/10.3201/ eid2402.171172

Salleh I, Baharuddin O, Sallehudin S, Juraihan S, Zuraidawati Z. 2003. Notes on the ectoparasites of rodents from the Ulu Gombak Forest Reserve, Selangor. Journal of Tropical Biomedicine. 20:159-163.

Sarwar M. 2017. Status of Argasidae (soft) ticks (Acari: Parasitiformes: Argasidae) in relation to transmission of human pathogens. International Journal of Vaccines and Vaccination. 4(4):00089. https://doi.org/10.15406/ijvv.2017.04.00089

Schipper J, Chanson JS, Chiozza F, Cox NA, Hoffmann M, Katariya V, Lamoreux J, Rodrigues ASL, Stuart SN, Temple HJ, et al. 2008. The status of the world's land and marine mammals: diversity, threat, and knowledge. Science. 322:225-230. https://doi.org/10.1126/science.1165115

Shields L, Twycross A. 2003. The difference between incidence and prevalence. Paediatric Nursing. 15(7):50-56.

Nor SM. 2001. Elevational diversity patterns of small mammals on Mount Kinabalu, Sabah, Malaysia. Global Ecology \& Biogeography. 10: 41-62.

Soliman S, Main AJ, Marzouk AS, Montasser AA. 2001. Seasonal studies on commensal rats and their ectoparasites in a rural area of Egypt the relationship of ectoparasites to the species locality and relative abundance of the host. Journal of Parasitology. 87:545-553. https://doi.org/10.1645/00223395(2001)087[0545:SSOCRA]2.0.CO;2 
Sparagano OAE, Allsopp MTEP, Mank RA, Rijpkema SGT, Figueroa JV, Jongejan F. 1999. Molecular detection of pathogen DNA in ticks (Acari: Ixodidae): a review. Experimental and Applied Acarology. 23:929-960.

Sponchiado J, Melo GL, Landulfo GA, Jacinavicius FC, Barros-Battesti DM, Cáceres NC. 2015. Interaction of ectoparasites (Mesostigmata, Phthiraptera and Siphonaptera) with small mammals in Cerrado fragments, western Brazil. Experimental and Applied Acarology. 66:369-381. https://doi.org/10.1007/s10493-015-9917-0

Strandtmann RW, Mitchell CJ. 1963. The laelaptine mites of the Echinolaelaps complex from the southwest pacific area (Acarina: mesostigmata). Pacific Insects. 5(3):541-576.

Sulaiman MH, Ho WC, Hassan M. 2016. Ectoparasite of Tupaia glis (Scandentia: Tupaiidae) from Lingai agricultural area, Terengganu. Asian Pacific Journal of Tropical Disease. 6(1):6-9. https://doi.org/10.1016/S2222-1808(15)60976-8

Sundararaman M, Boopathi T, Gopinath S. 2007. Status of mangrove ecosystem. Seckbach, J, editor. Algae and Cyanobacteria in Extreme Environments. Dordrecht (NL): Springer. p. 209-224. https://doi.org/10.1007/978-1-4020-6112-7

Thanee NS, Kupittayanant S, Pinmongkholgul S. 2009. Prevalence of ectoparasites and blood parasites in small mammals at Sakaerat Environmental Research Station, Thailand. Thai Journal of Agriculture Science. 42(3):149-158.

Tripathi RS. 2014. Integrated management of Rodent pests. In: Abrol DA, editor. Integrated Pest Management. New York; Academic Press. p. 419-459. https://doi.org/10.1016/B978-0-12-3985293.00022-1

Wells K, Lakim MB, O’Hara RB. 2014. Shifts from native to invasive small mammals across gradients from tropical forest to urban habitat in Borneo. Biodiversity and Conservation. 23(9):2289-2303. https://doi.org/10.1007/s10531-014-0723-5

Wood BJ. 1972. Sources of reinvasion of oil palms by the wood rat (Rattus tiomanicus). In: Wastie RL, Wood BJ, editors. Crop protection in Malaysia. Kuala Lumpur: The Incorporated Society of Planters. p.146-165.

Wood BJ, Chung GF. 2003. A critical review of the development of rat control in Malaysian agriculture since the 1960s. Journal of Crop Protection. 21:445-461. https://doi.org/10.1016/S02612194(02)00207-7

Yamaguti N, Tipton VJ, Keegan HL, Toshioka S. 1971. Ticks of Japan, Korea, and the Ryukyu Islands. Brigham Young University Science Bulletin, Biological Series. 15:1 -226.

Yamamura N. 1993. Vertical transmission and evolution of mutualism from parasitism. Theoretical Population Biology. 44:95-109. https://doi.org/10.1006/tpbi.1993.1020

Young HS, Dirzo R, McCauley DJ, Agwanda B, Cattaneo L, Dittmar K, Eckerlin RP, Fleischer RC, Helgen LE, Hintz A, et al. 2015. Drivers of intensity and prevalence of flea parasitism on small mammals in east African savanna ecosystems. Journal of Parasitology. 101(3):327-335. http://dx.doi.org/10.1645/14-684.1

Yusof MA, Mohd-Taib FS, Ishak SN, Md-Nor S, Md-Sah SA, Mohamed NZ, Azhari NN, Neela V, Sekawi Z. 2019. Microhabitat factors influenced the prevalence of pathogenic Leptospira spp. in small mammal host. EcoHealth. 16:260-274. https://doi.org/10.1007/s10393-019-01419-1

This article is distributed under the terms of the Creative Commons Attribution Noncommercial License (by-nc 4.0) which permits any noncommercial use, distribution, and reproduction in any medium, provided the original author(s) and source are credited. 